Hiroshi Okuda • Hiroyuki Fujiwara · Toshinori Omi Sadahiko Iwamoto $\cdot$ Masaki Kawano $\cdot$ Tomoko Ishida Shosaku Nomura • Shiro Fukuhara • Atsushi Nagai Isao Ohya • Eiji Kajii

\title{
A Japanese propositus with D-- phenotype characterized by the deletion of both the RHCE gene and D1S80 locus situated in chromosome 1p and the existence of a new CE-D-CE hybrid gene
}

Received: September 21, 1999 / Accepted: January 5, 2000

\begin{abstract}
In a family study of a Japanese propositus with the D-- phenotype, the serological data of her D-phenotype and those of her parents were discrepant. Gene analysis of the propositus showed a gross deletion of the RHCE gene and a new rearrangement of RHCE to yield the $C E-D-C E$ hybrid. It was demonstrated that the hybrid $C E-D-C E$ gene consisted of exon 1 from the $R H C E$ gene, followed by exons 3 to 7 from the $R H D$ gene and exons 8 to 10 from the RHCE gene. However, whether or not exon 2 of the $R H D$ or the $R H C E$ gene was contained in the $C E$ $D-C E$ gene remained unclear. Moreover, spacer analysis between both $R H$ genes and the family study suggested that the D-- gene complex from the paternal and maternal sides consisted of only the $C E-D-C E$ hybrid gene and a single $R H D$ gene, respectively. For the purpose of confirming the parent-child relationship, a paternity test using DNA fingerprint and polymerase chain reaction (PCR) analysis at the D1S80 locus were performed. DNA fingerprints with two kinds of DNA minisatellite probes (33.15 and 33.6) confirmed that the parent-child relationship in the D-propositus was compatible. However, in the present case, at the D1S80 locus, the PCR product derived from the mother was lacking, thereby negating a parent-child relationship. It is probable that the $R H$ genes and D1S80 locus exist in close proximity, because they are situated in chromosomes 1p 34.3-36.1 and 1p 36.1-36.3, respectively. These data suggested that at the stage of gametogenesis, both the
\end{abstract}

H. Okuda $(\bowtie) \cdot$ T. Omi $\cdot$ S. Iwamoto $\cdot$ M. Kawano $\cdot$ E. Kajii

Department of Legal Medicine and Human Genetics, Jichi Medical

School, 3311-1, Yakushiji, Minamikawachi-machi, Kawachi, Tochigi 329-0498, Japan

Tel. +81-28-558-7342; Fax +81-28-544-4902

e-mail: okudahir@jichi.ac.jp

H. Fujiwara

Department of Obstetrics and Gynecology, Jichi Medical, School,

Tochigi, Japan

T. Ishida $\cdot$ S. Nomura $\cdot$ S. Fukuhara

Transfusion Service, Kansai Medical University, Moriguchi, Japan

A. Nagai $\cdot$ I. Ohya

Department of Legal Medicine, Gifu University School of Medicine,

Gifu, Japan
RHCE gene and the D1S80 locus from the maternal side may have been deleted, thereby producing the $\mathrm{D}$-- gene complex.

Key words D-- phenotype $\cdot C E-D$ - $C E$ hybrid gene $\cdot R H$ genes $\cdot$ D1S80 locus $\cdot$ DNA fingerprints $\cdot$ Gametogenesis

\section{Introduction}

$\mathrm{Rh}$ is the most complex of the human blood group systems (Mollison et al. 1987) The major Rh antigens are $\mathrm{RhD}$, $\mathrm{RhC/c}$, and $\mathrm{RhE} / \mathrm{e}$. These $\mathrm{Rh}$ antigens are sulfhydryl-containing polypeptides carried by $30-\mathrm{kDa}$ to $32-\mathrm{kDa}$ transmembrane proteins (Green 1967; Gahmberg 1982; Moore et al. 1982; Green 1983). It has been demonstrated that the $\mathrm{RhD}$, Rhc, and RhE antigens are carried by homologous, but distinct, molecular species and that all share a common N-terminal protein sequence (Bloy et al. 1987; Avent et al. 1988; Saboori et al. 1988).

Recent molecular studies have resulted in the cloning of several cDNAs for Rh polypeptides (Avent et al. 1990; Cherif-Zahar et al. 1990; Le Van Kim et al. 1992a; Arce et al. 1993; Kajii et al. 1993); these can be divided into two different types showing a high level of sequence homology. Genomic DNA analyses have shown that the Rh locus of each haploid RhD-positive chromosome consists of two closely linked structural genes, RHD and RHCE, whereas it is made of a single gene, RHCE, on each haploid RhDnegative chromosome (Le Van Kim et al. 1992a; Colin et al. 1991; Hermand et al. 1993; Mouro et al. 1993). The RHD gene encodes the $\mathrm{RhD}$ polypeptide and the RHCE gene encodes both the $\mathrm{RhC/c}$ and $\mathrm{RhE} / \mathrm{e}$ polypeptides. It is thought that $\mathrm{RhC} / \mathrm{c}$ and $\mathrm{RhE} / \mathrm{e}$ antigens are carried by the same protein (Smythe et al. 1996). The RHCE gene comprises ten exons, ranging in size from 72 to $247 \mathrm{bp}$, distributed over $75 \mathrm{~kb}$. Intron sizes range from $1.5 \mathrm{~kb}$ to more than $10 \mathrm{~kb}$ (Cherif-Zahar et al. 1994a). The RHD gene structure is not yet completely known, but preliminary investigations indicate that it is similarly organized (Cherif- 
Zahar et al. 1994a). However, a 600-bp deletion in intron 4 of the RHD gene has been identified (Arce et al. 1993; Cherif-Zahar et al. 1994a).

Several variants lacking $\mathrm{RhC/c}$ and/or $\mathrm{RhE} / \mathrm{e}$ antigens have been reported, which include the D--, Dc-, $\mathrm{DC}^{\mathrm{w}}$-, $\mathrm{D}^{\mathrm{IV}}(\mathrm{C})-$, and D-- phenotypes (Race and Sanger 1975; Daniels, 1995). Among these variants, the D-- variant expresses no RhC, Rhc, RhE, or Rhe antigen. The frequency of the D-- complex was estimated roughly as 0.0005 in Sweden (Rasmuson and Heiken 1966), but about ten times that (0.0047) in Iceland (Olafsdottir et al. 1983). Okubo et al. (1983) tested 692,000 Japanese donors and detected 7 donors $(0.001 \%)$ with the D-- phenotype, a frequency of 0.0032 for the D-- gene. Recent molecular genetic analyses of the D-- variant have shown two genetic forms: the deletion and nondeletion types (Blunt et al. 1994; Cherif-Zahar et al. 1994b; Huang et al. 1995; Huang et al. 1996a; Kemp et al. 1996).

Here, we describe the molecular analysis of the D-- gene found in one member of a Japanese family. The D-- loci detected in the propositus showed a new $C E-D-C E$ hybrid gene and a gross deletion of the RHCE gene. The genomic deletion that seemed to have occurred at gametogenesis on the maternal side was accompanied by the detection not only of the RHCE gene but also of the D1S80 locus, thereby inducing discrepant data in the mother-child relationship testing.

\section{Materials and methods}

\section{Blood samples}

A Japanese woman with D-- phenotype and her family members (Fig. 1) were analyzed for the D-- gene complex. Anticoagulated whole blood $(20 \mathrm{ml})$ was drawn from the cubital vein after informed consent had been obtained. $\mathrm{RhD}$-positive and RhD-negative blood was used as controls.

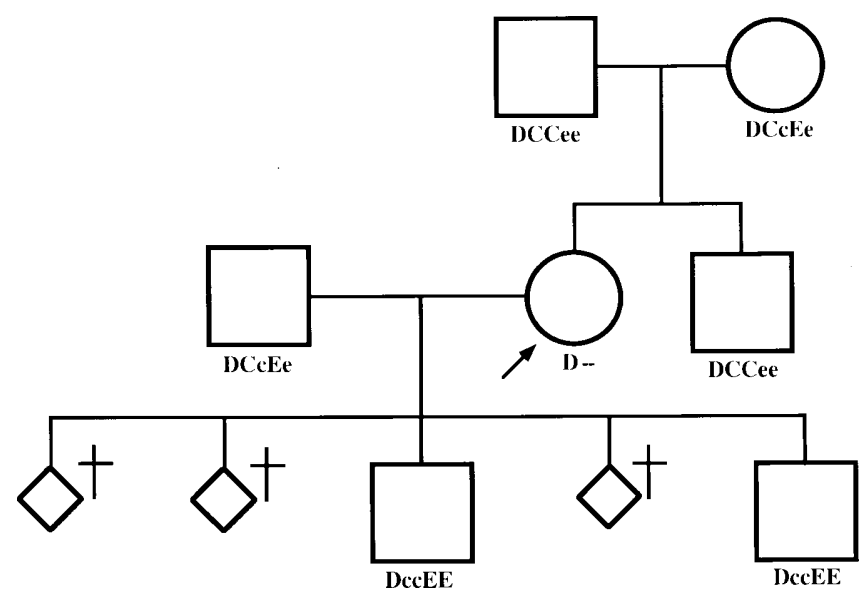

Fig. 1. Pedigree of a D-- family. Arrow shows propositus; crosses show

\section{Serological examination}

Serotyping for the $\mathrm{RhD}, \mathrm{RhC/c}$, and $\mathrm{RhE} / \mathrm{e}$ antigens was carried out with polyclonal and monoclonal anti-RhD, antiC, anti-c, anti-E, and anti-e antibodies (Ortho Diagnostic Systems, NJ, USA). In the D-- propositus, the presence of anti- $\mathrm{Hr}_{0}$ in her serum was examined (Okubo et al. 1983). The strength of $\mathrm{RhD}$ antigen in the $\mathrm{D}$-- propositus and a DCcEe phenotype as control were examined by direct agglutination of a saline suspension of red cells with polyclonal anti-RhD (IgG) antibody, respectively.

\section{RNA and DNA isolation}

Total RNAs of reticulocytes were isolated according to Tse et al. (1991). Genomic DNA was extracted from peripheral blood leukocytes according to a previously reported method (Sambrook et al. 1989).

Reverse transcription-polymerase chain reaction (RT-PCR)

Poly(A)+ RNA was reverse-transcribed into the first strand of cDNA with oligo $(\mathrm{dT})_{16}$ as a primer, using cloned Molony murine leukemia virus (M-MLV) reverse transcriptase. The reverse PCR was performed in a reaction tube using a Gene Amp RNA PCR kit (Perkin Elmer Cetus, Norwalk, CT, USA) by the method of Wang et al. (1989) and Erlich (1989). The two primers prepared for PCR and the sequencing on the basis of the published cDNA sequence of Rh polypeptides (Avent et al. 1990; Cherif-Zahar et al. 1990; Le Van Kim et al. 1992a) were as follows: F1(nt -30 to -11$)$; 5'-GTGGAACCCCTGCACAGAGA-3', and R1 (nucleotides nt 1283 to 1264); 5'CAGGCCTTGTTTTTCTTGGA-3'. PCR was performed with the first-strand cDNA as the template, at a final concentration of $1 \times$ PCR buffer $(10 \times$ PCR buffer $=15 \mathrm{mM}$ $\mathrm{MgCl} 2,100 \mathrm{mM}$ Tris- $\mathrm{HCl} \mathrm{pH} 8.3,500 \mathrm{mM} \mathrm{KCl}$ buffer), $0.24 \mu \mathrm{M}$ of each $5^{\prime}$ and $3^{\prime}$ primer, and 2.5U Taq DNA polymerase, in a total volume of $100 \mu$ l. The amplification scheme included denaturation at $94^{\circ} \mathrm{C}$ for $1 \mathrm{~min}$, primer annealing at $55^{\circ} \mathrm{C}$ for $1 \mathrm{~min}$, and extension at $72^{\circ} \mathrm{C}$ for $3 \mathrm{~min}$. After the completion of 35 cycles, the sample was subjected to a final 10 -min incubation at $72^{\circ} \mathrm{C}$. To evaluate the results of amplification, $5 \mu \mathrm{l}$ of the reaction mixture was withdrawn and electrophoresed in a $2 \%$ agarose gel. For the purpose of generating single-stranded DNA (ssDNA) templates, asymmetric PCR (Gyllensten and Ehrlich 1988) was performed against the double-stranded DNA (dsDNA), using an asymmetric ratio $(100: 1)$ of the two primers. The ssDNAs were prepared by internal primers in order to reduce errors involved in the sequencing of the PCRamplified DNAs.

Subcloning

RT-PCR products were ligated into $\mathrm{pCR}^{\mathrm{TMII}}$ with a TA cloning kit (Invitrogen, San Diego, CA, USA) according to 
the supplier's instructions. After transformation, the clones with the insert were screened by color selection with X-Gal. Each white colony was transferred into Luria-Bertani medium containing ampicillin at $100 \mathrm{mg} / \mathrm{ml}$, and the culture was incubated overnight at $37^{\circ} \mathrm{C}$. Plasmid DNAs were isolated by the alkaline lysis method (Sambrook et al. 1989) and were prepared for sequencing by the alkaline-denaturation method (Sambrook et al. 1989).

DNA sequencing and analysis

The ssDNA templates were sequenced by the dideoxy chain-termination method of Sanger et al. (1977), using a Sequenase DNA sequencing kit (Amersham, Buckinghamshire, England), as described by the manufacturer. The primers used were either sequence-specific oligonucleotides or the universal primer. The reaction products were electrophoresed on $6 \%$ acrylamide gels containing $8 \mathrm{M}$ urea.

Polymerase chain reaction (PCR) for $R H D$ and RHCE genes

For the detection of the $R H$ gene by PCR, four primers were prepared according to the reports of Arce et al. (1993) and Simsek et al. (1995) (Fig. 2A). These primers were as follows: F2 (nt 521 to 540); 5' -TGTTCGCAGCCTATTTTGGG-3', R2 (nt 670 to 651); 5' -TGACACTTGGCCAGAACATC-3', F3 (nt 1246 to 1268); 5'-GGATTTTAAGCAAAAGCATCCAA-3', and R3 (nt 1443 to 1422); 5'-CGATAAATGGTGAGATTCTCCT-3'. The primer
Fig. 2A,B. Analysis of organization of the $R H D$ and $R H C E$ genes at the $R H$ locus. A polymerase chain reaction (PCR) strategy for the $R H D$ and $R H C E$ genes is shown. Primers F2/R2 were used to amplify a 1225-bp fragment of the RHCE gene and a 576-bp fragment of the RHD gene in each intron 4. $R H D$-specific primers F3/R3 amplified a 198-bp fragment of exon 10 in the $R H D$ gene. B Genomic DNAs from the D-- propositus, parents, and normal volunteers with DCCee and dccee phenotypes were amplified by dual PCR, using two primer sets of F2/R2 and F3/ R3. The PCR products were separated on $2 \%$ agarose gel and stained with ethidium bromide

\section{(A)}

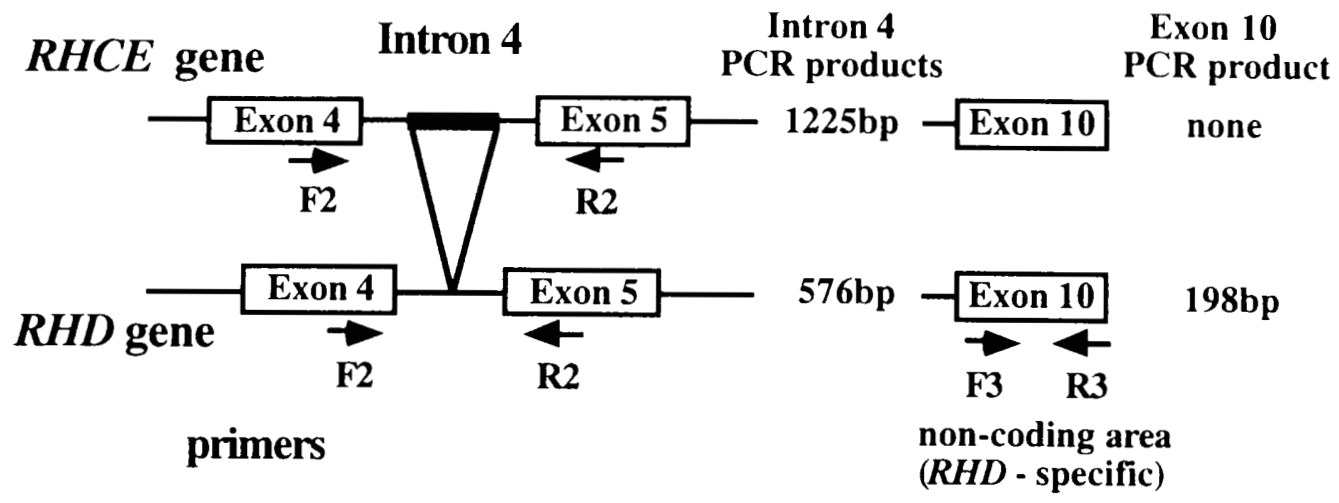

(B)

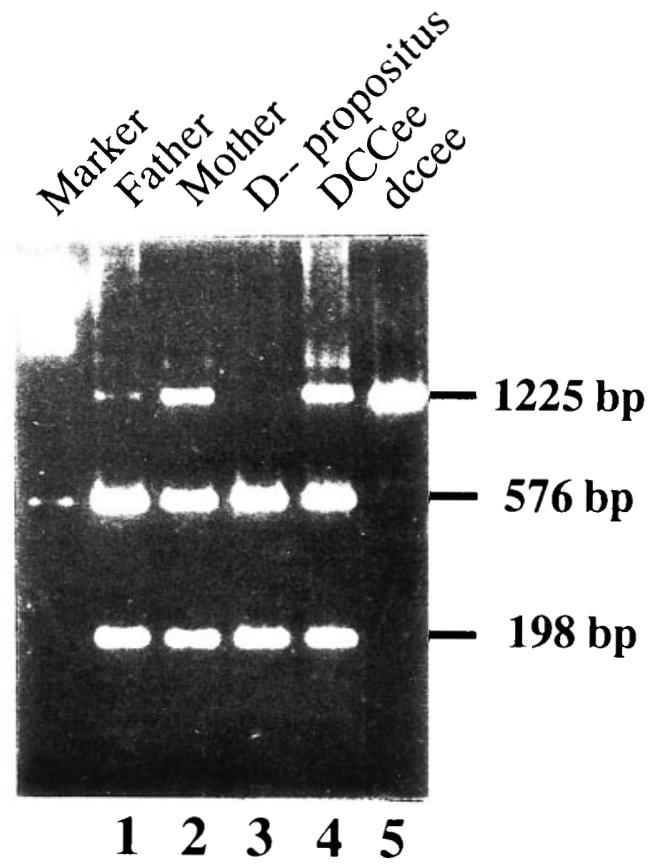


F2 for a sequence located in exon 4 and the primer R2 for a sequence located in exon 5 were used to distinguish the RHCE gene from the RHD gene (Arce et al. 1993; CherifZahar et al. 1994a). As shown in Fig. 2, the PCR products derived from the RHCE and RHD genes were $1225 \mathrm{bp}$ and $576 \mathrm{bp}$, respectively. The antisense primer F3 recognizes a sequence in the $3^{\prime}$ noncoding region of the RHD gene and therefore yields a product of $198 \mathrm{bp}$ only from the DNA of $\mathrm{RhD}$-positive donors (Simsek et al. 1995). In the presence of all four primers, a dual PCR was performed with the genomic DNA in the capacity of the template. The final concentration of the PCR mixture was $1 \times$ PCR buffer $(10$ $\times$ PCR buffer $=15 \mathrm{mM} \mathrm{MgCl} 2,100 \mathrm{mM}$ Tris-HCl $\mathrm{pH} 8.3$, $500 \mathrm{mM} \mathrm{KCl}$ buffer), $0.24 \mu \mathrm{M}$ of each $5^{\prime}$ and $3^{\prime}$ primer, and $2.5 \mathrm{UTaq}$ DNA polymerase in a total volume of $100 \mu \mathrm{l}$. The first cycle of the PCR was done at $95^{\circ} \mathrm{C}$ for $5 \mathrm{~min}$ to denature DNA; this was followed by 35 cycles of $1 \mathrm{~min}$ at $95^{\circ} \mathrm{C}$, $1 \mathrm{~min}$ at $55^{\circ} \mathrm{C}$, and $3 \mathrm{~min}$ at $72^{\circ} \mathrm{C}$, and finally 1 cycle of $10 \mathrm{~min}$ at $72^{\circ} \mathrm{C}$. To evaluate the results of amplification, $5 \mu$ l of the reaction mixture was withdrawn and electrophoresed in a $2 \%$ agarose gel.

For analyzing the RHCE gene, allele-specific amplification (ASPA) was carried out with the genomic DNA as the template. Exons 1,2, and 5 of the RHCE gene were amplified by seven primers according to Faas et al. (1995), Le Van Kim et al. (1994), and Tanaka et al. (1997), as shown in Fig. 3A. The primers were as follows: F4 (nt 31 to 48); 5'-CGCTGCCTGCCCCTCTGC-3', R4 (nt 148 to 128); 5'-CTTGATAGGATGCCACGAGCC3', F5 (nt 183 to 203); 5'CTTGGGCTTCCTCACCTCAAA-3', R5 (nt 290 to 271); 5'-AAGCCGTCCAGCAGGATTGC-3', F6 (nt 658 to 676); 5'-TGGCCACGTCAACTCTC-3', F7 (nt 658 to 676 ); 5'-TGGCCACGTGTCAACTCTG-3', R6 (nt 801 to 782$)$; 5'-CATGCTGATCTTCCTTTGGG-3'.

Two primers $(\mathrm{Sc} / \mathrm{Ac})$ to exon 3 were common to both the $R H D$ and $R H C E$ genes and were used as an internal control to validate the PCR reaction (Fig. 3). The Sc and Ac primers were as follows: Sc (nt 397 to 420); 5'-AAGGTCAACTTGGCGCAGTTGGTG-3', Ac (nt 486 to 462); 5'-GTTGAAGATATTACTGATGACCATC-3'.

The final concentration of the PCR mixture was $1 \times$ PCR buffer (same as above), 1.0 $\mu \mathrm{M}$ of each $5^{\prime}$ and $3^{\prime}$ primer, and 5UTaq DNA polymerase in a total volume of $100 \mu \mathrm{l}$. The first cycle of the PCR was performed at $94^{\circ} \mathrm{C}$ for $10 \mathrm{~min}$; this was followed by 35 cycles of $30 \mathrm{~s}$ at $95^{\circ} \mathrm{C}, 30 \mathrm{~s}$ at $64^{\circ} \mathrm{C}$, and $30 \mathrm{~s}$ at $72^{\circ} \mathrm{C}$. To evaluate the results of amplification, $5 \mu \mathrm{l}$ of the reaction mixture was withdrawn and electrophoresed in a 3\% agarose gel.

\section{Southern blot analysis}

DNAs obtained were digested with restriction endonuclease Sph I and analyzed by Southern blot hybridization as described (Umenishi et al. 1994a; Huang et al. 1996b). Exon-specific probes were generated by PCR from $\mathrm{RhD}$ cDNA probes, which ligated into $\mathrm{pCR}^{\mathrm{TMII}}$ with a TA cloning kit (Invitrogen) (Fig. 4). The primers were as fol-

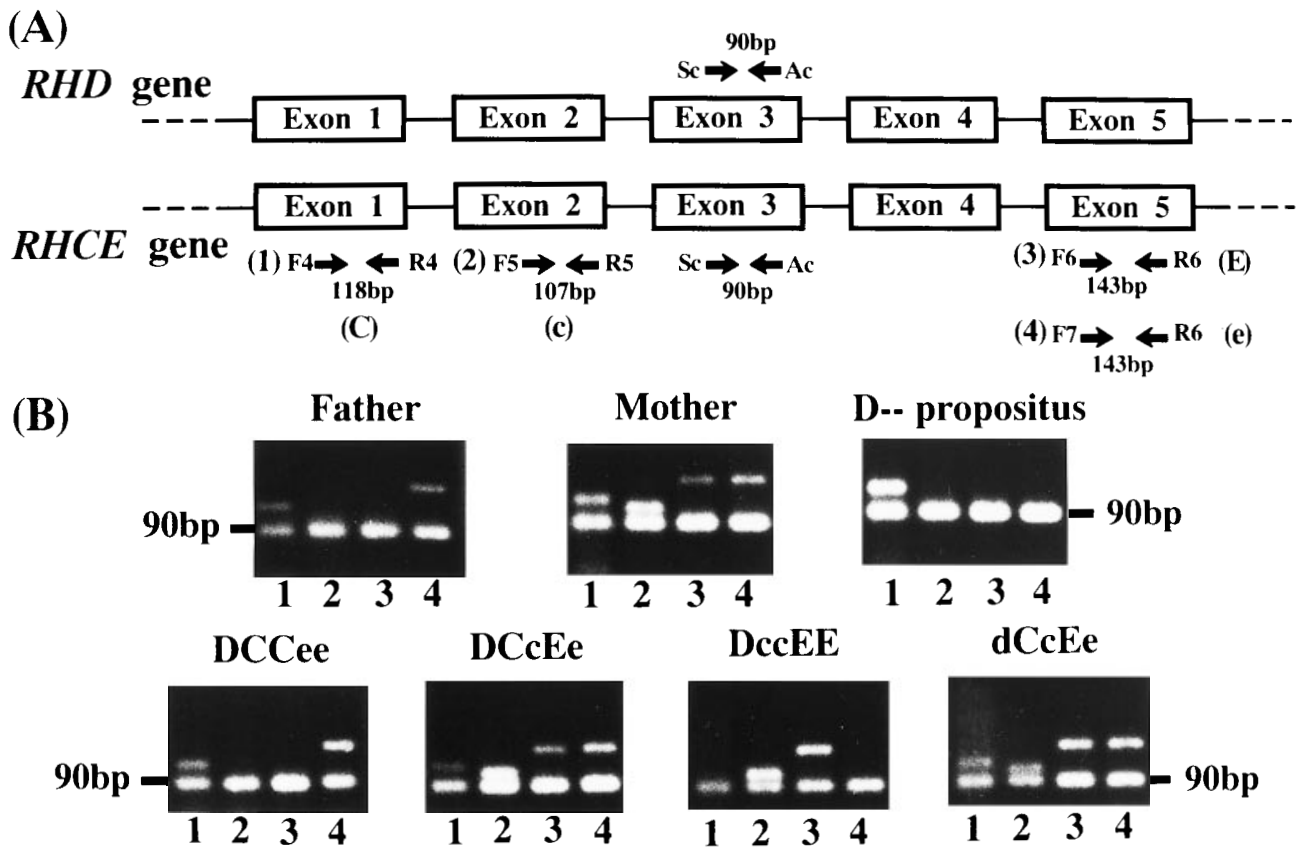

Fig. 3A,B. Allele-specific PCR amplification (ASPA) for the $R H C$, $R H c, R H E$, and $R H e$ alleles. A Schemed of ASPA strategy. Four primer sets, of F4/R4, F5/R5, F6/R6, and F7/R6, were prepared for ASPA of the $R H C, R H c, R H E$, and $R H e$ alleles, respectively. The 118bp, 107-bp, 90-bp, and 143-bp products were amplified by each set of allele-specific primers. Two primers (Sc/Ac) to exon 3 were common to both the $R H D$ and $R H C E$ genes and were used as an internal control to validate the PCR reaction. B Genomic DNAs from the D-- propositus, her parents, and four normal volunteers with DCCee, DCcEe, DccEE, and dCcEe were amplified by ASPA. The PCR products were separated on $3 \%$ agarose gel and stained with ethidium bromide. Lanes 1 through 4 contain the ASPA products of the $R H C, R H c, R H E$, and RHe alleles, respectively. Primers Sc/Ac amplified a 90-bp fragment (exon 3), which was used as an internal control 
Fig. 4. Scheme of exon-specific probes. Five exon-specific probes (exons $1 / 2$, exons $3 / 4$, exons $5 / 6$, exons $7 / 8$, and exons $9 / 10$ ) were prepared by amplifying full $\mathrm{RhD}$ cDNA ligated into $\mathrm{pCR}^{\mathrm{TMII}}$ with a ten-primer set (Se1-2/Ae1-2, Se3-4/Ae3-4, Se5-6/Ae5-6, Se78/Ae7-8, and Se9-10/Ae9-10). As the homology between $\mathrm{RhD}$ cDNA and RhCE cDNA in the coding region was about $97 \%$, these exon-specific probes were able to combine with the RHCE gene as well as the RHD gene

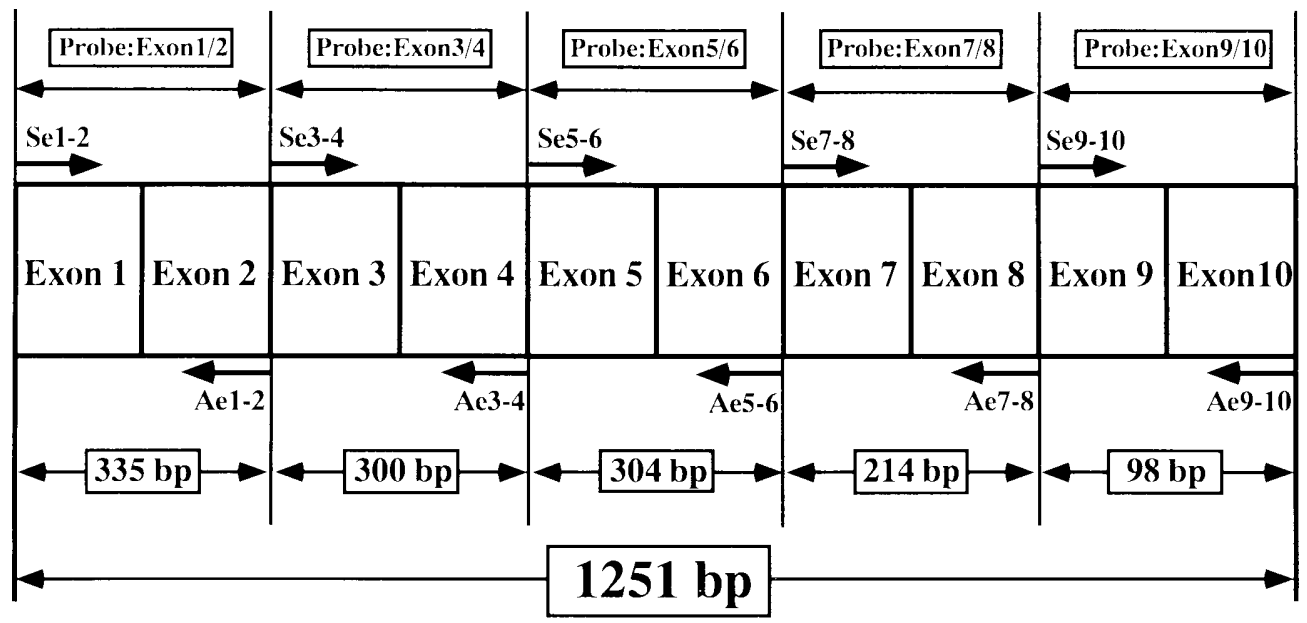

RhD cDNA coding region

lows: Se1-2: 5'-ATG AGC TCT AAG TAC CCG CG-3' (nt 1 to 20 ), Ae 1-2: 5' -CTG AAC AGT GTG ATG ACC AC$3^{\prime}$ (nt 335 to 316), Se 3-4: 5'-TAT TCG GCT GGC CAC CAT GA-3' (nt 336 to 355), Ae 3-4: 5'-CCC AGC ATG GCA GAC AAA CT-3' (nt 635 to 616), Se 5-6: 5'-CGC CCT CTT CTT GTG GAT GT-3' (nt 636 to 655), Ae 5-6: 5'-CGG CAG GTA CTT GGC TCC CC-3' (nt 939 to 920), Se 7-8: 5'-GTG TGT TGT AAC CGA GTG CT-3'(nt 940 to 959), Ae 7-8: 5' -CTG TCA GGA GAC CAG ACG TG$3^{\prime}$ (nt 1155 to 1134 ), Se 9-10: 5'-GTT TGC TCC TAA ATC TCA AA-3'(nt 1154 to 1173) and Ae 9-10: 5'-AAA TCC AAC AGC CAA ATG AG-3' (nt 1251 to 1232). The primer positions and probe sizes are shown in Fig. 4. The final concentration of PCR mixture was $1 \times$ PCR buffer $(10 \times$ PCR buffer $=15 \mathrm{mM} \mathrm{MgCl}_{2}, 100 \mathrm{mM}$ Tris- $\mathrm{HCl} \mathrm{pH} 8.3$, $500 \mathrm{mM} \mathrm{KCl}$ buffer), $0.24 \mu \mathrm{M}$ of each $5^{\prime}$ and $3^{\prime}$ primer, and 2.5UTaq DNA polymerase in a total volume of $100 \mu$ l. The first cycle of the PCR was done at $95^{\circ} \mathrm{C}$ for $5 \mathrm{~min}$ to denature DNA; this was followed by 35 cycles of $1 \mathrm{~min}$ at $95^{\circ} \mathrm{C}, 1 \mathrm{~min}$ at $55^{\circ} \mathrm{C}$, and $3 \mathrm{~min}$ at $72^{\circ} \mathrm{C}$, and finally 1 cycle of $10 \mathrm{~min}$ at $72^{\circ} \mathrm{C}$. The PCR products were purified through preparative agarose gel electrophoresis.

\section{PCR analysis at the D1S80 locus}

According to the method of Kasai et al. (1990), we examined the parent-child relationship by PCR amplification at the D1S80 locus. The PCR products were electrophoresed in polyacrylamide gel $(5 \% \mathrm{~T}, 4 \% \mathrm{C})$ with ethidium bromide stain.

Paternity test by DNA fingerprint analysis

After the preparation of genomic DNA digested by the restriction endonuclease Hinf I, DNA fingerprint analysis was performed with two kinds of DNA minisatellite probes (33.15 and 33.6) developed by Jeffreys et al. (1985a, 1985b, 1985c) and commercialized by Cellmark Diagnostics, USA.
Examination of the parent-child relationship was carried out according to the manufacturer's guidelines.

\section{Results}

\section{Serological examination}

Serologically, the Rh phenotypes of the propositus and her father, mother, brother, and sons were D--, DCCee, DCcEe, DCCee, and DccEE, respectively (Fig. 1). In the D-- propositus, anti- $\mathrm{Hr}_{0}$ antibody was identified. The red cells of the D-- propositus were directly agglutinated with polyclonal anti-RhD (IgG) antibody, but those of the DCcEe phenotype were not agglutinated. The strength of $\mathrm{RhD}$ antigen in the D-- propositus was enhanced.

Isolation and sequencing of cDNAs encoding $\mathrm{Rh}$ polypeptides

The detection of Rh polypeptide-mRNA has been accomplished using the RT-PCR method followed by direct sequencing. RT-PCR using Taq DNA polymerase was performed on $\mathrm{Rh}$ polypeptide-cDNAs from the $\mathrm{D}$-propositus and her parents, using a set of F1/R1 primers. After 35 cycles of amplification, the reaction products were separated by agarose gel electrophoresis and the fractionated bands were detected in all three samples at around $1313 \mathrm{bp}$, as expected. Additionally, the PCR products exhibited several faint bands migrating ahead of this band in all samples. For the purpose of purification of the Rh-related cDNAs, the RT-PCR products were subcloned with the plasmid $\mathrm{pCR}^{\mathrm{TMII}}$ vector. Sequence analyses revealed two clones, of a normal RhD cDNA and a hybrid CE-D-CE cDNA in the D-- propositus (Fig. 5). Her father demonstrated a normal RhCe cDNA in addition to these two cDNAs. In her mother, on the other hand, three clones, of intact RhD cDNA, intact RhCe cDNA, and 


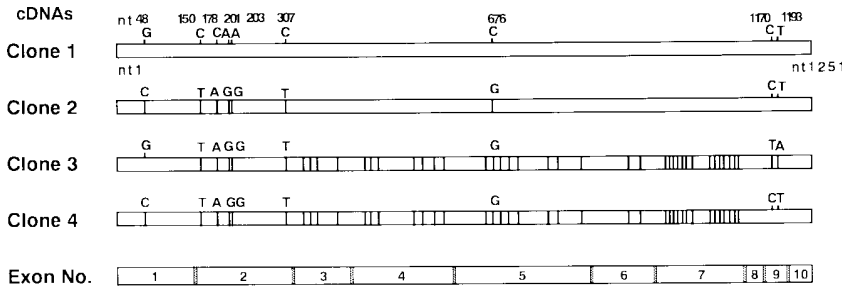

Fig. 5. Four cDNA clones isolated from the D-- propositus and her parents. Clones 1,2 , and 3 were derived from the $c E, C e$, and $D$ genes, respectively. Clone 4 was derived from the hybrid $C E-D-C E$ gene. RT PCR followed by subcloning and sequencing exhibited the presence of clones 3 and 4 in the D-- propositus, clones 2, 3, and 4 in the father and clones 1,2 , and 3 in the mother. The vertical lines indicate the nucleotide substitutions between clone 1 and the other clones. $n t$, Nucleotide

intact RhcE cDNA were found. Isoforms of mRNAs from the RHD and RHCE genes were also present as minor species (Le Van Kim et al. 1992b; Suyama et al. 1994; Umenishi et al. 1994b; Kajii et al. 1995).

The hybrid CE-D-CE cDNA showed an open reading frame of 1251 nucleotides and the composition of exons 1 and 9 from the RHCE gene and exons 3 to 7 from the RHD gene (Fig. 5). Exon 10 of this hybrid cDNA seemed to be derived from the RHCE gene through the analysis of products amplified by the PCR, using the 1s primer and an antisense primer corresponding to $R H C E$-specific sequences (nt 1382 to 1361). However, we could not determine whether exons 2 and 8 originated from the $R H C$ or $R H D$ genes, because the sequences of these exons are identical in the two genes (Le Van Kim et al. 1992a; Mouro et al. 1993).

\section{Detection of the $R H D$ gene by PCR}

The RHCE gene consists of ten exons (Cherif-Zahar et al. 1994a). The RHD gene structure is not yet completely known, but preliminary investigations have indicated that it is similarly organized (Cherif-Zahar et al. 1994a). However, a 649-bp deletion in intron 4 of the RHD gene has been identified (Okuda et al. 1997). The PCR amplifications for intron 4 of the RHCE and $R H D$ genes were carried out with the primer set F2/R2. Two products, of $1225 \mathrm{bp}$ and $576 \mathrm{bp}$, were amplified from RhD-positive donors, whereas a single product, of $1225 \mathrm{bp}$, was amplified from $\mathrm{RhD}$-negative donors (Fig. 2). In addition to the primer set for intron 4, another primer set $(\mathrm{F} 3 / \mathrm{R} 3)$ was prepared, which is specific for exon 10 of the $R H D$ gene only (Le Van Kim et al. 1992a; Simsek et al. 1995). Dual PCRs were performed with these F2/R2 and F3/R3 primer sets. The RhD-positive samples demonstrated three PCR products: $1225 \mathrm{bp}$ from intron 4 of the RHCE gene, $576 \mathrm{bp}$ from intron 4 of the $R H D$ gene, and $198 \mathrm{bp}$ from exon 10 of the RHD gene (Fig. 2B). The RhDnegative samples contained only a 1225 -bp product. In the D-- propositus, two products, of $576 \mathrm{bp}$ and $198 \mathrm{bp}$, were amplified, but not the 1225-bp product. In her mother, the PCR showed all three products. Although all three products were detected in her father, the quantity of the 1225-bp product was smaller than that of the others.

\section{Detection of the RHCE gene by ASPA}

Between the RHC and RHc allele, one nucleotide substitution at position 48 in exon 1 and five nucleotide substitutions, at positions 150,178, 201, 203, and 307 in exon 2 of the RHCE gene have been reported (Mouro et al. 1993). These six nucleotide substitutions resulted in four amino acid changes. Five kinds of primer sets were prepared to amplify specific regions of the RHCE gene. Primers F4/R4, F5/R5, F6/R6, and F7/R6 were used for the RhC-, Rhc-, RhE-, and Rhe-specific ASPAs, respectively (Fig. 3). Primers F4, F5, F6, and F7 are specific for the RHC, RHc, RHE, and RHe alleles, respectively (Tanaka et al. 1997). The results of these ASPAs for DNAs from the D-propositus, her parents, and four normal donors with various $\mathrm{Rh}$ phenotypes are shown in Fig. 3B. Primers F4/R4 amplified a 118-bp region of the RHCE gene (exon 1) in RhC-positive donors. Primers F5/R5 amplified a 107-bp fragment from donors carrying the RHc allele (exon 2). Primers F6/R6 amplified a 143-bp fragment (exon 5) from RhE-positive donors. In contrast, a 143-bp fragment (exon 5) amplified with primers F7/R6 was detected in Rhe-positive donors. Primers Sc/Ac amplified a 90-bp fragment (exon 3), which was used as an internal control. The ASPA showed only the RhC-specific product in the D-propositus, RhC- and Rhe-specific products in her father, and RhC-, Rhc-, RhE-, and Rhe-specific products in her mother (Fig. 3). By taking the results of the cDNA analysis in addition to the result of ASPA into consideration, it is thought that the D-- propositus did not possess the intact RHCE gene.

\section{Southern blot analysis}

Southern blot analysis was performed to further analyze the structure of the $\mathrm{RH}$ locus using exon-specific probes (Fig. 4). Sph I was used as a restriction endonuclease. The pattern of Southern blotting in normal individuals with $\mathrm{RhD}$-positive and $\mathrm{RhD}$-negative phenotypes corresponded to that reported by Huang et al. (1996b), who indicated that the $S p h$ I site in intron 5 was unique in the $D$ gene but was polymorphic for the non-D alleles. Accordingly, as shown in Fig. 6, there was a discrepancy between the patterns of bands generated from only the RHCE gene in the dCCdee donor without the RHD gene (lane 1) and the DCCee donor (lane 2). We determined the origins of bands with reference to the $S p h$ I map in the D-- family (Fig. 6). In the D-- propositus, the RHCE-specific bands could not be found with the probes of exons $3 / 4,5 / 6$, and $7 / 8$, whereas the $R H D$-derived bands were detected. The probe of exons 9/ 10 showed that the bands originated from the RHCE and $R H D$ genes of the D-- propositus. Among bands detected by exons $5 / 6$ and $7 / 8$, the $6.1-\mathrm{kb}$ band was found only in the D-- propositus and her father (Fig. 6). In addition, her father exhibited several additional bands which were not 


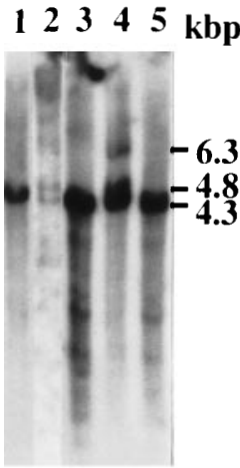

Exon 1/2

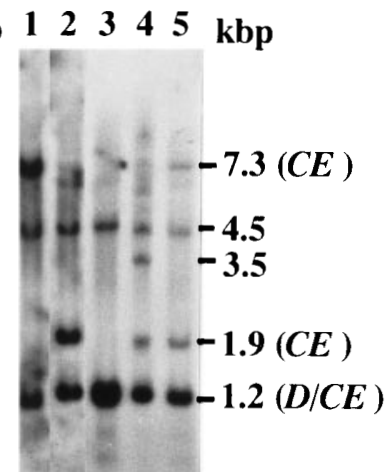

Exon 3/4

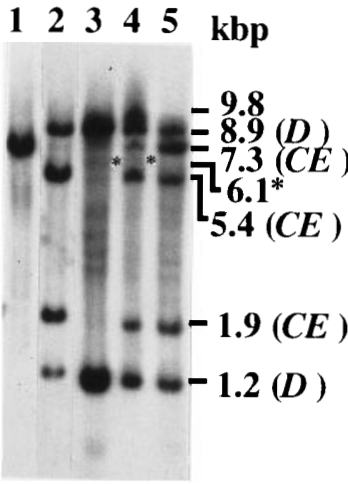

Exon 5/6

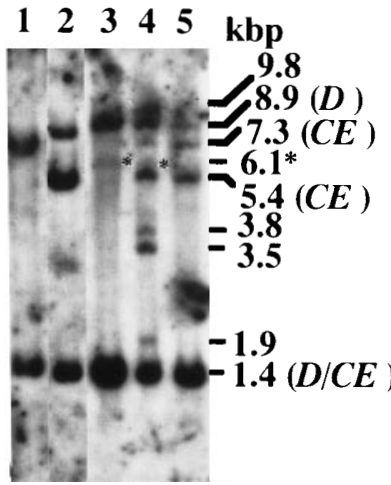

Exon 7/8

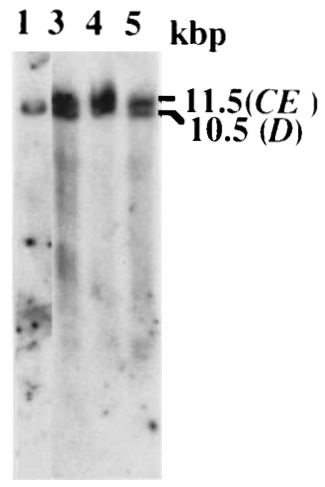

Exon 9/10

\section{Probes}

Fig. 6. Southern blot analysis. The DNAs digested by $S p h$ I were hybridized with five exon-specific primers of exons 1/2,3/4, 5/6, 7/8, and 9/10. DNAs were isolated from a dCCee donor without the $R H D$ gene (lane 1), a DCCee donor (lane 2), the D-- propositus (lane 3), her father (lane 4), and her mother (lane 5). The origins of bands were determined with reference to the Sph I map reported by Huang et al. (1996b). On Southern blot analysis with exons $5 / 6$ and $7 / 8$ probes, a $6.1-\mathrm{kb}$ band was found only in the D-- propositus and her father (asterisks). Huang et al. indicated that the $S p h$ I site in intron 5 was unique in the $D$ gene but was polymorphic for the non-D alleles (Huang et al. 1996b). Therefore, the fragments generated from only the RHCE gene in the dCCee donor without the RHD gene (lane 1) and DCCee donor (lane 2) were as follows: With the exon 3/ 4 probe, the dCCee donor (lane 1) and the DCCee donor (lane 2) possessed a 7.3-kbp band and a 1.9-kbp band, respectively. With the exon 5/6 probe, the dCCee donor (lane 1) and the DCCee donor (lane 2) had the 7.3-kbp band and both 1.9-kbp and 5.4-kbp bands, respectively. With the exon $7 / 8$ probe, the dCCee donor (lane 1) and the DCCee donor (lane 2) had the 7.3-kbp band and 5.4-kbp band, respectively observed in other individuals (Fig. 6). The band pattern of her mother was normal and revealed the presence of heterogeneous RHCE genes (Fig. 6). We could not clarify the difference between the RHD and RHCE genes using the probe of exons $1 / 2$.

Paternity test by DNA fingerprint and D1S80 locus analysis

In the Japanese, as the observed and expected heterozygosities at the D1S80 locus are 0.88 and 0.89 , respectively (Nagai et al. 1994), detection of two bands is more usual than detection of a single band. The mother and father of the propositus each possessed two bands (Fig. 7). The brother had two bands, derived from the mother and father. The D-- propositus showed only a single band which corresponded to one of the father's bands. Accordingly, it is thought that there was no parent-child relationship between the D-- propositus and the mother at the D1S80 locus. In the DNA fingerprint analysis, detectable fragments more than $3.5 \mathrm{kbp}$ in size (Jeffreys et al. 1991) were investigated with two kinds of multilocus probe (33.15 and 33.6) (Table 1, Fig. 8). We calculated the probability of the following two cases by means of binomial distribution to estimate the results in the DNA fingerprint analysis.

\section{Case A}

In the D-- propositus, the total number of bands inconsistent with both mother and putative father was 2 in DNA fingerprint analysis with the 33.15 probe and 0 in DNA fingerprint analysis with the 33.6 probe (Table 1 ). Jeffreys et
Table 1. The number of bands in DNA fingerprint analysis

\begin{tabular}{llll}
\hline & A & B & Total \\
\hline Mother & 29 & 20 & 49 \\
Father & 34 & 22 & 56 \\
D-- propositus & 31 & 21 & 52 \\
C & $15(13)$ & $10(9)$ & $25(22)$ \\
D & $18[16]$ & $10[9]$ & $28[25]$ \\
E & 0 & 2 & 2 \\
F & 2 & 1 & 3
\end{tabular}

A, number of bands observed in DNA fingerprint analysis with the 33.6 probe; $\mathrm{B}$, the number of bands observed in DNA fingerprint analysis with the 33.15 probe. In the $\mathrm{D}$-- propositus, $\mathrm{C}$ indicates the number of bands consistent with the mother, (in $\mathrm{C}-\mathrm{F}$, the numbers of bands specific to the mother are shown in parentheses); $\mathrm{D}$ indicates the number of bands consistent with the father (in D-F, the numbers of the bands specicific to the father are shown in brackets). E indicates the number of bands inconsistent with both mother and father. F indicates the number of bands common to both mother and father

al. (1991) reported that the degree of overlap between loci scored in the 33.6 and 33.15 fingerprints was negligible. Assuming that two bands (detected only in the 33.15 DNA fingerprint) that are not consistent with either the mother or the father are generated by mutation, the probability (PA) is:

$\mathrm{PA}=\mathrm{n}_{1} \mathrm{C}_{2} \mathrm{~m}_{1}^{2}\left(1-\mathrm{m}_{1}\right)^{\mathrm{n}_{1}-2} \times \mathrm{n}_{2} \mathrm{C}_{0} \mathrm{~m}_{2}^{0}\left(1-\mathrm{m}_{2}\right)^{\mathrm{n}_{2}}$

In the D-- propositus, $\mathrm{n}_{1}$ and $\mathrm{n}_{2}$ show the total number of bands observed in DNA fingerprint analysis with the 33.15 and 33.6 probes, respectively. $\mathrm{m}_{1}$ and $\mathrm{m}_{2}$ indicate the rate per band of mutation in DNA fingerprint analysis with the 33.15 and 33.6 probes, respectively.) As $\mathrm{n}_{1}=21$ and $\mathrm{n}_{2}=31$ (Table 1), $\mathrm{m}_{1}=0.011$ and $\mathrm{m}_{2}=0.0052$ (Jeffreys et al. 1991), these values are substituted in Eq. (1) to give 


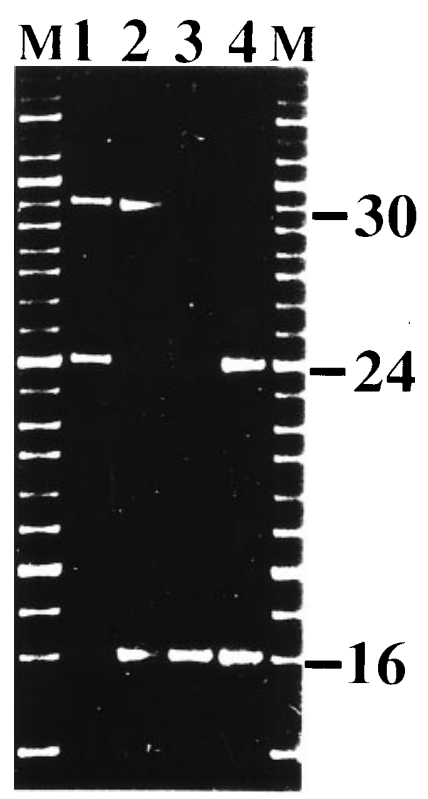

1. Mother

2. Brother

3. D-- propositus

4. Father M: Marker

Fig. 7. PCR amplification analysis at the D1S80 locus in the D-- family. In the D-- family, the paternity test was performed by PCR amplification analysis at the D1S80 locus. The numbers of tandem repeat $(30,24$, and 16) are shown on the right side of the electrophoretic picture. Both the mother (30 and 24) and father (24 and 16) possess two fragments. The brother has two bands (30 and 16) derived from the mother and father. On the other hand, in the D-- propositus, only a fragment (16) derived from the father exists and the band from the maternal side is lacking. Accordingly, the parent-child relationship at the D1S80 locus was denied. Lane M, Marker; lane 1, mother; lane 2, brother; lane 3, D-- propositus; lane 4, father

$\mathrm{PA}=1.74 \times 10^{-2}$.

\section{Case B}

Assuming that all bands in the D-- propositus are not consistent with the mother's and are accidentally derived from the putative father, the probability $(\mathrm{PB})$ that the true father is other than the putative father is:

$\mathrm{PB}=\sum_{\mathrm{N}} \mathrm{C}_{\mathrm{K}} \mathrm{Y}^{\mathrm{K}}(1-\mathrm{Y})^{\mathrm{N}-\mathrm{K}}$

$\mathrm{K}=\mathrm{N}-\mathrm{d}, \cdots, \mathrm{N}-1, \mathrm{~N}$ where $\mathrm{N}$ is the total number of bands in the D-- propositus inconsistent with the mother; $\mathrm{K}$, the number of bands accidentally derived from the putative father in the aforesaid case; $d$, the total number of bands in the D-- propositus inconsistent with both mother and father; and Y, the rate per band at which the same fragments are present in non-consanguineous kinships [we used the maximal rate reported by Jeffreys et al. (1985b and 1991).] As $\mathrm{N}=27(=52-25), \mathrm{d}=2$ (Table 1$)$, and $\mathrm{Y}=0.25$, these values are substituted in Eq. (2) to give
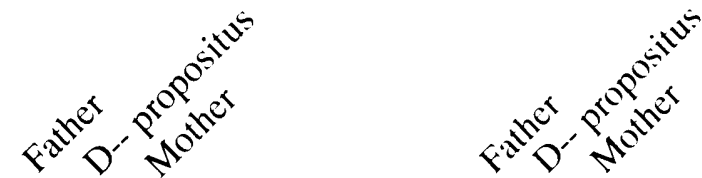

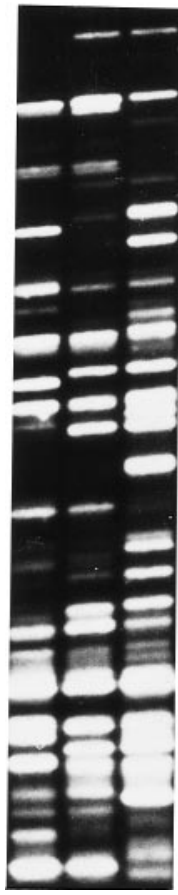

33.6

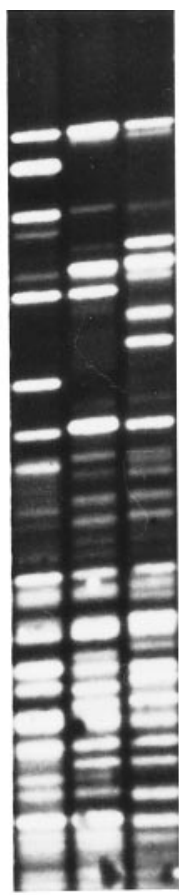

33.15
Probe

Fig. 8. Paternity test by DNA fingerprint analysis. Detectable bands more than $3.5 \mathrm{kbp}$ in size were analyzed with two kinds of multilocus probe (33.15 and 33.6). The numbers of bands in the father, mother, and D-- propositus, respectively, are shown in Table 1. Calculation of the probability of two cases to estimate the results of DNA fingerprint analysis affirmed the parent-child relationship (see text for probability calculation)

$\mathrm{PB}=1.80 \times 10^{-13}$.

Comparing PA with $\mathrm{PB}, \mathrm{PA}>>\mathrm{PB}$ and $\mathrm{PB}$ is nearly 0 . There is little possibility that accidental correspondence with the fragments between the D-- propositus and the putative father has occurred. It is thought that, in the D-propositus, two bands inconsistent with both mother and father have been generated by mutation. Accordingly, the parent-child relationship in the present family with the D-propositus was affirmed by the DNA fingerprint analysis.

\section{Discussion}

The D-- variant is serologically silent for $\mathrm{RhC/c}$ and $\mathrm{RhE} / \mathrm{e}$ antigens. The $\mathrm{RH}$ locus structure in donors homozygous for the D-- gene complex was analyzed. Race and Sanger (1975) remarked on the high incidence of consanguinity in the parents of D-- individuals. In an Icelandic family (Blunt et al. 1994) and an Italian family (Huang et al. 1995), the phenotype was explained by a deletion of the RHCE gene. However, in a French family (Cherif-Zahar et al. 1994b), 
both the RHD and RHCE genes were present and both transcripts had a normal sequence, thus suggesting a defect in transcriptional regulation of the RHCE gene.

We have investigated the structure and expression of $R H$ genes in a Japanese propositus with the D-- phenotype. The parents of this D-- propositus had no consanguinity. The serotyping of $\mathrm{Rh}$ phenotypes showed discrepant data between the propositus and her mother (DCcEe). By making use of DNA fingerprint analysis, however, the parent-child relationship in the present family with the D-- propositus was fully confirmed.

Many $\mathrm{Rh}$ variants arise through a gene conversion event by which a segment of one $R H$ gene $(R H D$ or $R H C E)$ is replaced by its homologous counterpart in the other gene (RHCE or RHD) (Cherif-Zahar et al. 1994b; Huang et al. 1996a; Kemp et al. 1996; Cartron 1994; Cherif-Zahar et al. 1996; Rouillac et al. 1995). This is a well documented mechanism that frequently occurs between tandemly arranged loci. Gene conversion appears to be the principal mechanism for gene diversity, and polymorphisms clearly exist (Cherif-Zahar et al. 1994b; Huang et al. 1996a; Kemp et al. 1996; Cartron 1994; Cherif-Zahar et al. 1996; Rouillac et al. 1995). A variety of gene rearrangements may occur by gene conversion, resulting in new hybrid structures of the $D-C E-D$ or $C E-D-C E$ genes (Cherif-Zahar et al. 1994b; Huang et al. 1996a; Kemp et al. 1996; Cartron 1994; CherifZahar et al. 1996; Rouillac et al. 1995). The new hybrid alleles generated by gene conversion potentially encode hybrid proteins that may exhibit unusual characteristics in terms of structure and antigenic properties.

The present study of the D-- complex showed a new hybrid $C E-D-C E$ gene composed of exon 1 from the $R H C E$ gene, followed by exons 3 to 7 from the $R H D$ gene and exons 8 to 10 from the RHCE gene (Fig. 5, Fig. 9, Fig. 10). It was difficult to determine whether exons 2 and 8 of this hybrid gene originated from an $R H C$ or $R H D$ allele be- cause these exon sequences are identical in the two genes (Mouro et al. 1993). We detected the $3^{\prime}$ hybrid site in intron 7 by Southern blot analysis, but not the $5^{\prime}$ hybrid site. The hybrid site is shown in Fig 9. The 6.1-kb band, which was found only in DNAs from the D-- propositus and her father, was considered to have originated from the $C E-D$ $C E$ gene (Fig. 6, Fig. 9). The Rh polypeptide derived from this hybrid gene appeared to lose the $\mathrm{Rh} \mathrm{C} / \mathrm{c}$ and $\mathrm{E} / \mathrm{e}$ antigens. Between the $R H D$ and $C E-D-C E$ genes, there was one nucleotide change in exon 1 and two nucleotide changes in exon 9, producing two amino-acid substitutions. These two amino acids were situated in the transmembrane and cytoplasmic domains, respectively. The sequence along the $R H D$ gene was identical to the RHc allele on exon 1 and the $R H C$ allele along exon 2 . This hybrid $C E-D-C E$ gene was identical to the $R H C$ allele on both exons 1 and 2 . The hybrid gene gave the RhD polypeptide the potential to express the $\mathrm{RhC}$ antigen. Along exon 5, the $R H D$ and $C E$ $D-C E$ genes encoded the Ala at 226 giving the potential to express the Rhe antigen. However, in the D-- propositus, we did not detect either the RhC or Rhe antigens. This result indicates the conformation-dependent nature of these antigens.

Similar hybrid $C E-D-C E$ gene structures also occurred at the Dc- locus and the DC ${ }^{\mathrm{w}}$ - locus (Cherif-Zahar et al. 1994b). Cherif-Zahar et al. (1994b) described exon rearrangements with the RHCE gene for two individuals who had the Dc- and $\mathrm{DC}^{\mathrm{w}}$ - phenotypes in which antigen expression was abolished. The Dc- gene complex comprised a $C E-D-C E$ hybrid transcript in which the $R H C E$ gene had exons 4 to 9 replaced with the corresponding $R H D$ gene exons (Cherif-Zahar et al. 1994b). Similarly, for the DC ${ }^{\mathrm{w}}$ complex, exons 3 to 9 were absent in the RHCE gene, and at least exon 3 (and probably the others) was replaced with the $R H D$ exon. Huang et al. (1996a) reported the $C E-D-C E$ hybrid gene which possessed a segmental transfer from the
Fig. 9. Scheme of $S p h$ I-digested fragments in the RHD, RHCE, and $C E-D-C E$ genes hybridized by the probe of exons $5 / 6$ and $7 / 8$ in Southern blot analysis. The triangles show the Sph I-digestive sites. These Sph I sites were predicted by the result of Southern analysis (Fig. 6). The white and black boxes indicate the RHD and RHCE genes, respectively. Assuming that the $3^{\prime}$ hybrid site of the $C E-D-C E$ gene exists in intron 7 , it is compatible that the $6.1-\mathrm{kb}$ band is detected only in the D-- propositus and her father. In the case that the Sph I site in intron 5 exists for the RHCE gene polymorphism, the $7.3-\mathrm{kbp}$ band originated from only the RHCE gene is divided into the $1.9-\mathrm{kbp}$ and the $5.4-\mathrm{kbp}$ fragments (Huang et al. 1996b). However, the $1.9-\mathrm{kbp}$ fragment cannot be hybridized with the exon $7 / 8$ probe



$\triangle: S p h$ I site 
Fig. 10. Scheme of the hybrid genes in previously reported D--, Dc-, and D-- cases and the present D* propositus. D-- (1), D* (1), and Dc- were reported by CherifZahar et al. (1994b; 1996). D* (2) (3) and D.* (3) were demonstrated by Kemp et al. (1996). D* (2) was shown by Huang et al. (1996a). D-- (4) is the present D-- propositus. In cases for which it was difficult to determine whether exon 2 of these hybrid genes originated from the RHCE or the $R H D$ gene, exon 2 is indicated by a diagonally shaded box Black boxes, RHCE gene; white boxes, $R H D$ gene; E, exon
D--
E: Exon

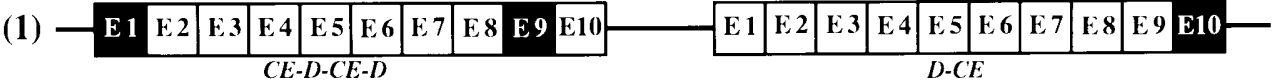

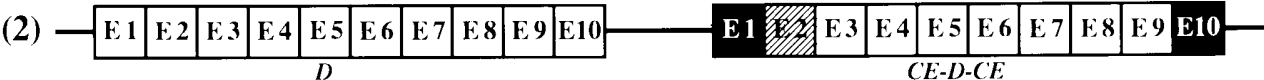

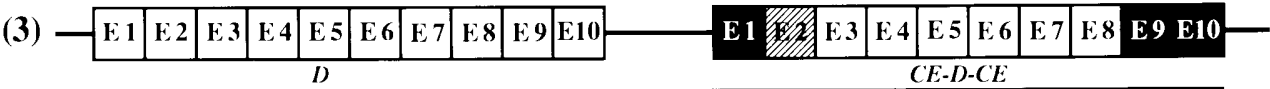
(4)

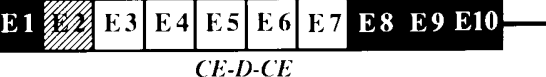

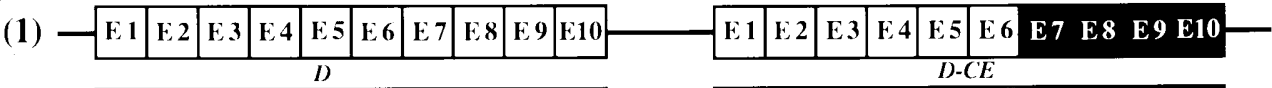

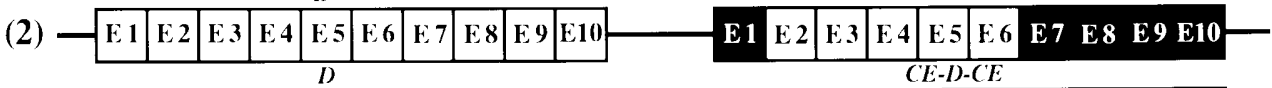

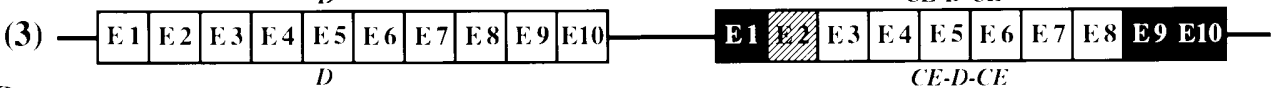
D.・

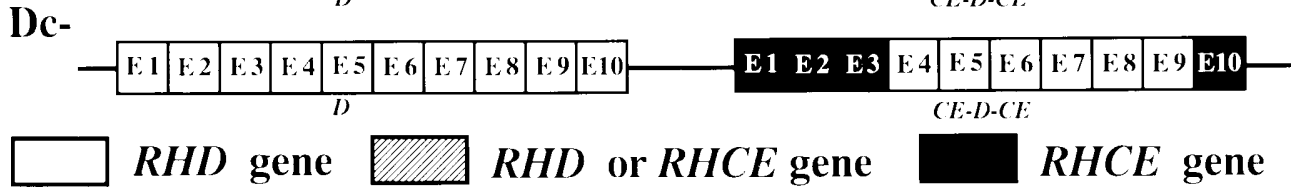

RHD gene to the RHCE gene covering exons 2-6. Kemp et al. (1996) showed two kinds of $C E-D-C E$ hybrid genes, which possessed exons 2 or 3-8 and exons 2 or 3-9 of the RHD gene, respectively. Moreover, Cherif-Zahar et al. (1996) reported the D-- phenotype characterized by both the $C E-D-C E-D$ and the $D-C E$ genes (Fig. 10).

In the present $\mathrm{D}$-- propositus, we were able to detect the intact $R H D$ gene and the hybrid $C E-D-C E$ gene but not the RHCE gene. In addition to the D-- complex, Southern blot analysis of the father suggested the existence of an abnormal structure in the other RH complex (Fig. 6). However, the abnormality is still unresolved. Spacer analysis between both the RHD and RHCE genes (data not shown) and the family study suggested that the D-complex from the paternal and maternal sides consisted of only a $C E-D-C E$ hybrid gene and a single $R H D$ gene, respectively (Fig. 11). However, the Rh phenotype of the mother was serologically determined to be DCcEe. We had two hypotheses for explaining this discrepant event between the propositus and her mother. Figure 12A shows that, in the two alleles of the mother, one possesses two RHCE genes and one or no RHD gene, and the other has only a single $R H D$ gene; otherwise, at the stage of gametogenesis, the RHCE gene from the maternal side may be deleted (Fig. 12B).

In 1985, hypervariable minisatellite regions in human DNA were found by Jeffreys et al. (1985a). As individual identification was performed, just like palmar fingerprints, by making use of hypervariable minisatellite regions, this method was named DNA fingerprinting. In recent years, DNA fingerprint analysis has been employed in forensic science, especially in paternity testing.

It was confirmed that the D1S80 locus was situated in chromosome 1p 36.1-36.3 (Nakamura et al. 1988; White et al. 1990) and contained a variable number of tandem repeats (VNTR). The polymorphism based on VNTR is
1.Allele derived from mother

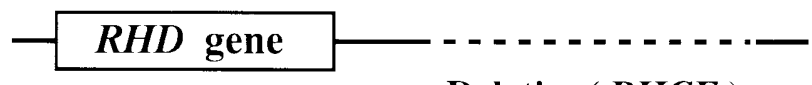

Deletion( $R H C E$ )

\section{Allele derived from father}

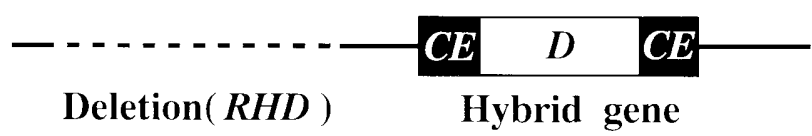

Fig. 11. Genetic model of the D-- propositus. Spacer analysis between both $R H$ genes (data not shown) and the family study suggested that the D-- complex from the paternal and maternal sides consisted of only the $C E-D-C E$ hybrid gene and a single $R H D$ gene, respectively. It is probable that the RHCE gene in the allele derived from mother and the $R H D$ gene in the allele derived from father are lacking

utilized for paternal testing, as well as for personal identification. In the present family, the mother-child relationship determined by DNA fingerprint analysis and by PCR amplification at the D1S80 locus was discrepant. As the $R H$ genes were located in chromosome 1p 34.3-36.1 (White et al. 1990; Cherif-Zahar et al. 1991), the $R H$ genes and D1S80 locus appeared to exist in close proximity on chromosome $1 \mathrm{p}$. These data suggest that the region containing both the $R H$ genes and D1S80 locus may have been deleted at the stage of gametogenesis (Fig. 12B), thus explaining why the discrepancies between the data for DNA fingerprinting and D1S80 locus analysis and between the Rh phenotypes in the propositus and her mother occurred. Plachot et al. (1987) reported that the incidence of various chromosomal abnormalities (haploidy, polyploidy, breakage, deletion, and extra chromosomes) in unfertilized mature human oocytes reached $32 \%$ and the incidence of abnormal babies was only $0.6 \%$. Martin et al. (1986) and 
(A)

\section{RHD gene RHCE gene RHCE gene}

\section{RHD gene}

(B)



Fig. 12A,B. Two hypotheses for explaining the event in the mother that led to discrepancy between the mother and the propositus. A One allele may possess two RHCE genes and one or no RHD gene, while the other may have only a single $R H D$ gene (Fig. 11). B The $R H C E$ gene in the thus one-sided allele may be deleted at the stage of gametogenesis in the mother, and thus the D-- complex genes may be produced (Fig. 11). There is some possibility that the number of $R H D$ genes is one or two in both cases $\mathbf{A}$ and $\mathbf{B}$

Wramsby et al. (1987) found in chromosomal abnormalities in $34 \%$ and $50 \%$ of oocytes, respectively. On the other hand, Martin et al. (1983) reported that $8 \%$ of spermatozoa carried chromosomal anomalies. According to these data, the incidence of chromosomal abnormalities, especially in oocytes, is very high. There is a good possibility that the region containing both the $R H$ genes and the D1S80 locus was deleted at the stage of maternal gametogenesis. However, at present, it is difficult to determine whether this hypothesis is correct. By analyzing the relative position between the $R H$ genes and D1S80 locus, we will be able to obtain genetic data in the neighborhood of both $R H$ genes. We believe that this new information will be beneficial for further research on the $\mathrm{Rh}$ blood group system.

Acknowledgments We are grateful to T. Seno (Osaka Red Cross Blood Center) for valuable discussions. This work was supported by a Grant-in-Aid (no.07671220) for Scientific Research from the Ministry of Education, Science, and Culture of Japan.

\section{References}

Arce MA, Thompson ES, Wagner S, Coyne KE, Ferdman BA, Lubin DM (1993) Molecular cloning of RhD cDNA derived from a gene present in $\mathrm{RhD}$-positive, but not $\mathrm{RhD}$-negative individuals. Blood 82:651-655

Avent ND, Ridgwell K, Mawby WJ, Tanner MJA, Anstee DJ, Kumpel B (1988) Protein-sequence studies of Rh-related polypeptides suggest the presence of at least two groups of proteins which are associated in the human red-cell membrane. Biochem J 256:1043-1046

Avent ND, Ridgwell K, Tanner MJ, Anstee DJ (1990) cDNA cloning of a $30 \mathrm{kDa}$ erythrocyte membrane protein associated with $\mathrm{Rh}$ (Rhesus)-blood-group-antigen expression. Biochem J 271:821-825

Bloy C, Blanchard D, Lambin P, Goossens D, Rouger P, Salmon C, Catron J-P (1987) Human monoclonal antibody against Rh(D) anti- gens: partial characterization of the $\mathrm{Rh}(\mathrm{D})$ polypeptide from human erythrocyte. Blood 69:1491-1497

Blunt T, Steers F, Daniels G, Carritt B (1994) Lack of RH C/E expression in the rhesus D-- phenotype is the result of a gene deletion. Ann Hum Genet 58:19-24

Cartron JP (1994) Defining the Rh blood group antigens. Biochemistry and molecular genetics. Blood Rev 8:199-212

Cherif-Zahar B, Bloy C, Le Van Kim C, Blanchard D, Bailly P, Hermand P, Salmon C, Cartron J-P, Colin Y (1990) Molecular cloning and protein structure of a human blood group $\mathrm{Rh}$ polypeptide. Proc Natl Acad Sci USA 87:6243-6247

Cherif-Zahar B, Mattei MG, Le Van Kim C, Bailly P, Cartron J-P, Colin Y (1991) Localization of the human Rh blood group gene structure to chromosome region $1 \mathrm{p} 34.3-1 \mathrm{p} 36.1$ by in situ hybridization. Hum Genet 86:398-400

Cherif-Zahar B, Le Van Kim C, Rouillac C, Raynal V, Cartron J-P, Colin Y (1994a) Organization of the gene (RHCE) encoding the human blood group $\mathrm{RhCcEe}$ antigens and characterization of the promoter region. Genomics 19:68-74

Cherif-Zahar B, Raynal V, D'Ambrosio AM, Cartron J-P, Colin Y (1994b) Molecular analysis of the structure and expression of the RH locus in individuals with D--, Dc- and $\mathrm{Dc}^{\mathrm{w}}$ - gene complexes. Blood 84:4354-4360

Cherif-Zahar B, Raynal V, Cartron J-P (1996) Lack of RHCE-encoded proteins in the D-- phenotype may result from homologous recombination between the two $R H$ genes. Blood 88:1518-1520

Colin Y, Cherif-Zahar B, Le Van Kim C, Raynal V, Van Huffel V, Cartron J-P (1991) Genetic basis of the RhD-positive and RhDnegative blood group polymorphism as determined by Southern analysis. Blood 78:2747-2752

Daniels G (1995) Human blood groups. Blackwell Science, Oxford

Erlich HA (1989) PCR technology: principles and application of DNA amplification. Stockton Press, New York

Faas BH, Simsek S, Bleeker PM, Overbeeke MA, Cuijpers HT, von dem Borne AE, van der Schoot CE (1995) Rh E/e genotyping by allele-specific primer amplification. Blood 85:829-832

Gahmberg CG (1982) Molecular identification of the human $\mathrm{Rh}_{0}(\mathrm{D})$ antigen. FEBS Lett 140:93-97

Green FA (1967) Erythrocyte membrane sulfhydryl groups and Rh antigen activity. Immunochem 4:247-257

Green FA (1983) The mode of attenuation of erythrocyte membrane $\mathrm{Rh} 0$ (D) antigen activity by 5,5'-dithiobis-(2-nitrobenzoic acid) and protection against loss of activity by bound anti- $\mathrm{Rh}_{0}(\mathrm{D})$ antibody. Mol Immunol 20:769-775

Gyllensten UB, Erlich HA (1988) Generation of single-stranded DNA by the polymerase chain reaction and its application to direct sequencing of the HLA-DQR locus. Proc Natl Acad Sci USA 85:7652-7656

Hermand P, Huet MM, Bloy C, Suyama K, Goldstein JP, Cartron J-P, Bailly P (1993) Immunochemical characterization of Rhesus proteins with antibodies raised against synthetic peptides. Blood 82:669676

Huang C-H, Reid ME, Chen Y (1995) Identification of a partial internal deletion in the $\mathrm{RH}$ locus causing the human erythrocyte D-- phenotype. Blood 86:784-790

Huang C-H, Chen Y, Reid M, Ghosh S (1996a) Genetic recombination at the human $R H$ locus: A family study of the red-cell Evans phenotype reveals a transfer of exons 2-6 from the RHD to the RHCE gene. Am J Hum Genet 59:825-833

Huang C-H, Reid ME, Chen Y, Coghlan G, Okubo Y (1996b) Molecular definition of red cell Rh haplotypes by tightly linked SphI RFLPs. Am J Hum Genet 58:133-142

Jeffreys AJ, Wilson V, Thein SL (1985a) Hypervariable "minisatellite" regions in human DNA. Nature 314:67-73

Jeffreys AJ, Wilson V, Thein SL (1985b) Individual-specific "fingerprints" of human DNA. Nature 316:76-79

Jeffreys AJ, Brookfield JFY, Semeonoff R (1985c) Positive identification of an immigration test-case using human DNA fingerprints. Nature 317:818-819

Jeffreys AJ, Turner M, Debenham P (1991) The efficiency of multilocus DNA fingerprint probes for individualization and establishment of family relationships, determined from extensive casework. Am J Hum Genet 48:824-840

Kajii E, Umenishi F, Iwamoto S, Ikemoto S (1993) Isolation of a new cDNA clone encoding a $\mathrm{Rh}$ polypeptide associated with the $\mathrm{Rh}$ 
blood group system. Hum Genet 91:157-162

Kajii E, Umenishi F, Omi T, Ikemoto S (1995) Intricate combinatorial patterns of exon splicing generate multiple Rh-related isoforms in human erythroid cells. Hum Genet 95:657-665

Kasai K, Nakamura Y, White R (1990) Amplification of a variable number of tandem repeats (VNTR) locus (pMCT118) by the polymerase chain reaction (PCR) and its application to forensic science. J Forensic Sci 35:1196-1200

Kemp TJ, Poulter M, Carritt B (1996) A recombination hot spot in the $\mathrm{Rh}$ genes revealed by analysis of unrelated donors with the rare $\mathrm{D}$ - phenotype. Am J Hum Genet 59:1066-1073

Le Van Kim C, Mouro I, Cherif-Zahar B, Raynal V, Cherrier C, Cartron J-P, Colin Y (1992a) Molecular cloning and primary structure of the human blood group RhD polypeptide. Proc Natl Acad Sci USA 89:10925-10929

Le Van Kim C, Cherif-Zahar B, Raynal V, Mouro I, Lopez M, Cartron J-P, Colin C (1992b) Multiple Rh messenger RNA isoforms are produced by alternative splicing. Blood 80:1074-1078

Le Van Kim C, Mouro I, Brossaed Y, Chavinie J, Cartron J-P, Colin C (1994) PCR-based determination of Rhc and RhE status of fetuses at risk of Rhc and RhE haemolytic disease. Br J Haematol 88:193195

Martin RH, Balkan W, Burns K, Rademaker AW, Lin CC, Rudd NL (1983) The chromosome constitution of 1,000 human spermatozoa. Hum Genet 63:305-309

Martin RH, Mahadevan MM, Taylor PJ, Hildebrand K, Long-Simpson L, Peterson D, Yamamoto J, Fleetham J (1986) Chromosomal analysis of unfertilized human oocytes. J Reprod Fertil 78:673-678

Mollison PL, Engelfriet CP, Contreas M (1987) Blood transfusion in clinical medicine, 8th edn. Blackwell, Oxford

Moore S, Woodrow CF, McClelland DBL (1982) Isolation of membrane components associated with human red cell antigens. $\mathrm{Rh}(\mathrm{D})$, (c), (E) and Fya. Nature 295:529-531

Mouro I, Colin Y, Cherif-Zahar B, Cartron J-P, Le Van Kim C (1993) Molecular genetic basis of the human Rhesus blood group system. Nature Genet 5:62-65

Nagai A, Yamada S, Bunai Y, Ohya I (1994) Analysis of the VNTR locus D1S80 in a Japanese population. Int J Legal Med 106:268-270

Nakamura Y, Carlson M, Krapcho V, White R (1988) Isolation and mapping of a polymorphic DNA sequence (pMCT118) on chromosome 1p (D1S80). Nucleic Acids Res 16:9364

Okubo Y, Tomita T, Nagao N, Yamaguchi H, Tanaka M (1983) Mass screening donors for -D- and $\mathrm{Jk}(\mathrm{a}-\mathrm{b}-)$ using Groupamatic-360. Transfusion 23:362-363

Okuda H, Kawano M, Iwamoto S, Tnaka M, Seno T, Okubo Y, Kajii E (1997) The RHD gene is highly detectable in RhD-negative Japanese donors. J Clin Invest 100:373-379

Olafsdottir S, Jensson O, Thordarson G, Sigurdardottir S (1983) An unusual Rhesus haplotype, -D-, in Iceland. Forensic Sci Int 22:183187

Plachot M, de Grouchy J, Junca AM, Mandelbaum J, Turleau C,
Couillin P, Cohen J, Salat-Baroux J (1987) From oocyte to embryo: a model, deduced from in vitro fertilization, for natural selection against chromosome abnormalities. Ann Genet 30:22-32

Race RR, Sanger R (1975) Blood groups in man, 6th edn. Blackwell, Oxford

Rasmuson M, Heiken A (1966) Frequency of occurrence of the human Rh complexes D(C)(e), d(c)(e), D-- and ---. Nature 212:1377-1379

Rouillac C, Colin Y, Hughes-Jones NC, Beolet M, D'Ambrosio A-M, Cartron JP, Le Van Kim C (1995) Transcript analysis of D category phenotypes predicts hybrid Rh D-CE-D proteins associated with alteration of D epitopes. Blood 85:2937-2944

Saboori AM, Smith BL, Agre P (1988) Polymorphism in the $\mathrm{Mr}$ $32,000 \mathrm{Rh}$ protein purified from $\mathrm{Rh}(\mathrm{D})$ positive and negative erythrocytes. Proc Natl Acad Sci USA 85:4042-4045

Sambrook J, Fritsch EF, Maniatis T (1989) Molecular cloning. A laboratory manual, 2nd edn. Coldspring Harbor Laboratory Press, New York

Sanger F, Nicklen S, Coulson AR (1977) DNA sequencing with chain terminating inhibitors. Proc Natl Acad Sci USA 74:5463-5467

Simsek S, Faas BH, Bleeker PM, Overbeeke MA, Cuijpers HT, van der Schoot CE, von dem Borne AE (1995) Rapid RhD genotyping by polymerase chain reaction-based amplification of DNA. Blood 85:2975-2980

Smythe JS, Avent ND, Judson PA, Parsons SF, Martin PG, Anstee DJ (1996) Expression of $R H D$ and $R H C E$ gene products using retroviral transduction of K562 cells establishes the molecular basis of Rh blood group antigens. Blood 19:2968-2973

Suyama K, Lunn R, Haller S, Goldstein J (1994) Rh(D) antigen expression and isolation of a new $\mathrm{Rh}(\mathrm{D})$ cDNA isoform in human erythroleukemic K562 cells. Blood 84:1975-1981

Tanaka M, Seno T, Shibata H, Okubo Y, Okuda H, Kajii E, Utsumi R (1997) Genotyping for $\mathrm{RhC/c}$ and $\mathrm{RhE} / \mathrm{e}$ by PCR using allelespecific oligonucleotide primers. Jpn J Legal Med 51:32-38

Tse WT, Gallagher PG, Pothier B, Costa F, Scarpa A, Delaunay J, Forget BG (1991) An insertional frameshift mutation of the betaspectrin gene associated with elliptocytosis in spectrin mice (beta220/216). Blood 78:517-523

Umenishi F, Kajii E, Ikemoto S (1994a) A new genetic polymorphism of Rh polypeptide genes. Biochem J 299:203-206

Umenishi F, Kajii E, Ikemoto S (1994b) Identification of two Rh mRNA isoforms expressed in immature erythroblasts. Biochem Biophys Res Commun 198:1135-1142

Wang AM, Doyle MV, Mark DF (1989) Quantitation of mRNA by the polymerase chain reaction. Proc Natl Acad Sci USA 86:9717-9721

White R, Lalouel J-M, Lathrop M, Leppert M, Nakamura Y, O'Connell P (1990) Human genetic linkage maps. In: O'Brien SJ (ed) Genetic maps, 5th edn. Cold Spring Harbor Laboratory Press, New York, pp 134 (book 5)

Wramsby H, Fredga K, Liedholm P (1987) Chromosome analysis of human oocytes recovered from preovulatory follicles in stimulated cycles. N Engl J Med 316:121-124 